\title{
Problems and Countermeasures of Experiential Ideological and Political Education in Colleges and Universities
}

\author{
Wei Dai \\ Century College, Beijing University of Posts and Telecommunications \\ Beijing, China 102101
}

\begin{abstract}
As a brand-new mode of ideological and political education, experiential education pays more attention to college students' self-experience and feelings in Ideological and political education, so that college students can receive education in experience. This paper probes into the connotation and characteristics of experiential ideological and political education, analyzes the problems existing in the implementation of experiential ideological and political education in Colleges and universities, and puts forward corresponding countermeasures on the basis of, namely, changing the ideological and political education concept, respecting students' subjectivity, constructing a new media information exchange level, and establishing a scientific evaluation mechanism.
\end{abstract}

Keywords - colleges and universities; experiential education; ideological and political education

\section{INTRODUCTION}

As the main channel of ideological and political education of university students, the ideological and political theory course is the main approach for students to establishing the correct political direction and setting up a scientific world outlook, outlook on life and values. [1] With the construction of socialism with Chinese characteristics entering the new era, the society has put forward higher requirements on talent training mode of colleges and universities. In accordance with the new requirements of the new era, education should also strive to build a classroom full of affinity and appeal, which is lively and energetic, cognitive and emotional. The content of ideological and political theory teaching should be internalized into the internal needs of college students, and internalized in daily behaviors, thus the educational effect of ideological and political education can be continuously enhanced. Since traditional ideological and political education in universities is more manifested in education methods such as didactic and infusion approach, it is too rigid to stimulate the initiative and enthusiasm of college students, sometimes even evoke their reverse psychology; therefore the satisfying education effect cannot be guaranteed. Different from the traditional infusion mode and teaching mode, the experiential education mode pays more attention to the emotion and experience of college students and their sense of acquisition in the education of ideology and politics. So, adopting this mode meets the requirement of the development and change of the times and adapts to the characteristic of the complex and changeable thought of the current college students.

\section{CONNOTATION AND CHARACTERISTICS OF EXPERIENTIAL IDEOLOGICAL AND POLITICAL EDUCATION}

Experiencing can be said to be one of the ways of life Life itself, according to Dilthey, is an irresistible impulse, in constant motion and change. In this process, one can only feel and grasp his or her relation with the world through mental experience. The world and individuals are inextricably interwoven with each other. In the spirit wealth of human, there are two equally important components, that is, knowledge and experience The former is the blood of human's rational world, the latter the nourishment of human's irrational world."[2] According to American scholar B Joseph Pine, experience is "the beautiful feeling generated in a person's consciousness when he reaches a certain level of emotion, physical strength, intelligence and even spirit." [3]Experiential ideological and political education is an ideological and political education value that takes experience as the medium to promote students' physical and mental health and all-round ideological development. It is a kind of education that educators use the basic theory, technology and method of experiencing education to guide and influence the educated and it is the most effective method of education internalization."[4] It focuses on the study of participants' daily practical activities, the stimulation of their emotional expression, and the understanding of their inner experience. The objective of experiential politics education is to enable participants to obtain real feelings and experiences through their own experience activities and thus generate internalized emotions and externalized behaviors, so as to promote their cognitive and thought enhancement. It features the participants' deep understanding of education content, sensibility and the orientation of education goals. Whether the education experience is successful or not depends on whether the participants can get truly emotional in the process of practical experience. It is highly emotional. Participants often experience the real meaning of life based on their own experience and self-accumulated emotions. The process is usually a new process of emotion generation, 
which contains deep perception of life. Compared with the traditional mode of ideological and political education, experiential education of ideological politics is embodied in the following characteristics.

\section{A. Subjectivity}

The experiential model fully respects the subject status of college students in the process of ideological and political education. In this process, the subjectivity of college students is fully reflected. As the experiencer, whether it is the practical behavior or the psychological feeling in the education process of ideology and politics, learning theory or self-thought, are students' self-experience, which belongs to students' subjective sense of gain. And different individuals have different experiences. "Such experience can only be the inner perception, introspection, which cannot be done by others. [5] Therefore, experiential ideological and political education pays attention to the inner feelings of students and emphasizes the enhancement of their inner experience to perceive the external world, rather than just the passive receiving indoctrination.

\section{B. Emotion}

As the core of education activity of experiential ideology and politics, emotion plays a very important role. In the process of practice experiencing, related emotion is bound to occur. And the emotional sublimation can bring the expected education effect. When college students actively participate in the specific process of experiential ideological and political education activities, they tend to actively integrate their inner feelings into specific activities, so the education can have distinct emotional feelings and achieve the realization of the effect of experiential ideological and political education.

\section{Interaction}

Experiential education mode of ideology and politics is embodied in placing college students in a certain teaching scene, where college students can communicate with each other about their experiences and feelings in practical activities in the process of accepting education, so as to deepen cognition and promote behavioral improvement through interaction. In addition, the experiential education mode of ideological and political learning pays more attention to the subject status of students and gives full play to their enthusiasm, initiative and creativity. In this education process, educators are no longer the authority of knowledge impart in the education process, but become the instructors, and the relationship between teachers and students develops into an equal interactive communication.

\section{Practicalness}

To enhance the effectiveness of college students' ideological and political education is inseparable from the cooperation and participation of various concrete practical activities, which are the bridge between teaching and learning. Experience is an irreplaceable link in education practice of ideology and politics. When accepting education of ideology and politics, college students take an active part in education activities and social practice activities of various themes where they feel and accumulate emotional experience in person so as to deepen the cognition of education content of ideology and politics, strengthen moral cultivation, will quality, and firm and correct ideals and beliefs.

\section{THE PROBLEMS EXISTING IN THE IMPLEMENTATION OF EXPERIENTIAL IDEOLOGICAL AND POLITICAL EDUCATION IN COLLEGES AND UNIVERSITIES}

\section{A. Traditional Ideological and Political Education Concepts}

In some colleges and universities, teachers have been the only subjects in the education process of ideological and political education over time. With traditional ideological and political education concepts, such as didactic and infusing deeply rooted in their mind, and lack of understanding of the education concept of experiential ideology and politics, these teachers still adopt the traditional teaching mode and their consciousness of innovation is in shortage. All these hinder the implementation of experiential ideological and political education in colleges and universities. Regard professional course teaching as the only task, some professional course teachers ignore the ideological and political education for students, and emphasize the training of students' professional skills alone. Therefore the absence of "civilization" affects the improvement of students' comprehensive quality, and impedes the real implementation of experiential politics education.

\section{B. Neglect of the Dominant Position of Students}

Traditional ideological and political education ideals and models have been prevailing. First of all, it is manifested in the one-sided view of the educators-centered outlook that believes ideological and political educators are the only subjects in the process of education, completely ignore the dominant role of the college students and only regard them as the objects of passively accepting education. This onesided education subjectivity will inevitably lead to the tendency of command-ism, coercive subjugation and oneway injection in the ideological and political education of college students, which seriously discourages and suppresses the initiative and enthusiasm of college students in the ideological and political education. [6] Of course, education course of ideology and politics cannot be separated from the imparting of theories. When the "post-1995" generation, who are rich in personality and subject consciousness, become the subject of college students, the traditional "I say you listen" one-way indoctrination model is clearly no longer working. According to the survey, more than 70 percent of students said they had little or no active participation in class presentation, class discussions or keynote speeches; nearly $90 \%$ of students believe that teachers should pay attention to the situational nature of teaching, the interesting content and the diversity of teaching methods in the teaching process. Karl Jaspers once mentioned that education teaching activities should give full play to the subjective initiative of the educated, to let them continuously realize self-cognition, 
self-experience and self-growth in specific practical activities. The teaching method based on collective "indoctrination" fails to pay enough attention to the dominant status of students. It neglects the interaction between students and teachers, and fails to pay attention to the ideological dynamics and behavioral tendency of the educated in time. As a result, the inner thoughts of students cannot receive timely attention and correct guidance from teachers, resulting in their low participation and enthusiasm in learning. Moreover, some teaching contents are seriously divorced from the reality of social life, or fail to pay attention to the intrinsic needs of students. Teaching cases are outdated and lack of pertinence, and cannot keep up with the trend of the times, which makes it difficult to arouse students' interest in participation. These problems will lead to the superficialness of ideological and political education, and it is difficult for students to improve their ideological and moral quality.

\section{Single Online Teaching Platform}

As the socialism with Chinese characteristics has entered a new era, the Internet has been quietly integrated into every aspect of college students' daily life and study with its irresistible power. It has a great impact on the daily life style and thinking mode of college students with the characteristics of large amount of information, fast transmission speed and rich and miscellaneous contents and has become an important way for college students to acquire knowledge and information on a daily basis. With the rapid development of new media, college students are not only receivers of information, but also transmitters of information. Their understanding of society no longer just depends on a single, one-way traditional mode, but also has more abundant options. This more efficient way of obtaining information overturns the traditional single and closed communication mode and forms an unimpeded state in time, space and information. While facilitating the life and study of college students, it also brings about the difficulty in controlling their access to information. To a large extent, it increases the difficulty of guiding discourse power and public opinion in the ideological and political education of colleges and universities, and makes the ideological and political education of colleges and universities appear complexity and diversification. Due to the low degree of informatization in some colleges and universities, the construction of network teaching platform is not perfect, and the interaction between teachers and students is affected. It is difficult for teachers to grasp the ideological dynamics of students, which affects the pertinence of education in ideological politics.

\section{Unreasonable Evaluation System}

Compared with traditional education mode of ideological and political, experiential education pays more attention to students' sense of acquisition in exploratory learning and practical activities. The onefold traditional ideological and political education evaluation and assessment system cannot meet the needs of experiential ideological and political education assessment any longer. At present, the education assessment and evaluation system of ideology and politics in some colleges and universities still follows the traditional assessment system with the assessment of theoretical knowledge as the main evaluation system that does not pay attention to students' experience. As long as students learn by rote before the test, they can get fine test scores and higher scores without in-depth understanding and mastery of education content. For the practical part, educators often only require students to write a practical paper or report, and take this as the evaluation basis, which is difficult to achieve the evaluation purpose. The lack of an effective evaluation system ultimately discourages students from participating in the experience. Their lack of attention and enthusiasm to participate in the practical activities of ideological and political education, make it difficult to achieve the established effect of experiential ideological and political education.

\section{COUNTERMEASURES FOR OPTIMIZING THE COLLEGE EXPERIENTIAL IDEOLOGICAL AND POLITICAL EDUCATION}

\section{A. Transforming the Concept of Ideological and Political Education}

With the continuous advancement of higher education system reform today, as the ideological and political education workers in colleges and universities, they must change the traditional ideological and political education concept, constantly improve their ability of self-innovation, and establish the experiential ideological and political education concept as soon as possible. On the one hand, the competent department of ideological and political education work and educators in colleges and universities must accurately grasp the law of ideological and political education of college students; actively transform their education concept of ideology and politics, create a good atmosphere of ideology and politics education, and allow students to accept the education of ideology and politics in their personal experience of practical activities. In the specific teaching practice, the competent department of ideological and political education and educators in colleges and universities should combine the actual situation of ideological and political education in colleges and universities promote the experiential ideological and political education mode as a new education concept and education mode, and conduct theoretical research, practical improvement and summary and evaluation. Therefore a systematic education system of college students' experiential ideology and politics can be established. On the other hand, the innovative consciousness of the ideological and political education workers should be attached importance to and enhanced. For the ideological and political course teachers, in addition to encouraging them to improve their teaching level to successfully complete the teaching tasks, the school should also encourage them to actively explore and study the experiential ideological and political education course design, teaching content, teaching methods and teaching evaluation thus to change the wrong idea of emphasizing the theoretical teaching of curriculum and ignores of experiential practice teaching. For front-line political and industrial cadres, they should make full use of their natural advantages of being close to the daily study and life of college students. They should go deep into students, and actively guide and organize 
college students to participate in rich ideological and political education activities to let them experience the sense of gain in practical activities, and therefore improve the ideological and moral quality.

\section{B. Respecting Students' Subjectivity}

The essence of the implementation of experiential ideological and political education is that educators continuously guide students to practice the education content, and sublimate and internalize the cognition and practice it in behaviors. Therefore, whether students' subjectivity can be fully respected, their subjective initiative given play to, and students can get real experience and feelings or not, is the key to the success of experiential ideological and political education. First of all, the main content of experiential teaching is to fully respect the subject status of students, truly grasp the needs of students and enhance the pertinence of education ideological and political activities. The experiential activities should be closely related to students' daily life to enhance their interest. For students, their respective different life experience has become an important part of their own life experience. Only by fully respecting the subjectivity of students and being closely aligned with their real life can education activities better arouse the resonance of students, really cause their thoughts and perception. Secondly, respect for the subjectivity of students is also reflected in the full consideration of the personality characteristics and cognitive differences of students in practical activities to improve the enthusiasm and interest of college students in participating in education activities and let them really feel the effect of experience. Therefore the ideological and political education can be really targeted effective. Finally, in the design of specific practical activities, the subjectivity of college students should be given full play to, to leave students more room for full play, and encourage them to actively explore and communicate. Of course, teachers should also actively guide students in practical activities and give full play to their initiative and initiative. Teachers' participation is also a test of the design effect of practical activities in the meantime. Teachers should participate in the whole process on the basis of respecting students' subjectivity, and then constantly improve the design of practical activities.

\section{Building a New Media Information Exchange Platform}

As the socialism with Chinese characteristics has entered a new era, and information technology influences all aspects of people's life and learning, the Internet is still an important part of college students' daily life and learning. Especially with the advent of the era of "we media", it has become an important way of life for contemporary college students to learn and communicate with emerging media technologies. Some students are inseparable from mobile phones both in class and after class. Phubbing group and refresh group have gradually become hot words. The rich network resources with fast dissemination speed, has become an important channel for students to acquire knowledge. The new situation requires education means to be innovated constantly. Multimedia teaching and network teaching have gradually replaced the relatively abstract and rigid teaching forms in the past with their vivid and intuitive images, which have obvious promoting effects on stimulating students' interest in learning, improving classroom attraction and enhancing ideological and political teaching effects. Therefore, the ideological and political education of colleges and universities should adapt to the changes of The Times and the reality of student development by making new media a powerful helper for colleges and universities to strengthen and improve the ideological and political education of college students. Students can accept ideological and political education from rich Internet experience, experience the vitality and appeal of education in the pleasure of receiving information. Therefore a subtle effect of ideological and political education can be achieved. Firstly, the construction of education network media platform for ideological and political education in colleges and universities should be strengthened. Teachers should strengthen their exchange of ideas with students inside and outside the class through improving WeChat group, QQ group, their personal micro blog, so as to grasp students' private ideological needs. Secondly, we should constantly strengthen the construction of new media of ideological and political education that is dominated by WeChat moments and public accounts. WeChat public number and experience platform for ideological and political theory courses in colleges and universities should be established to be a powerful complement to the synchronous daily classroom teaching. They should also be in line with students' ideological and psychological needs and clarify the negative impact of western ideas of hedonism, liberalism and individualism on college students in time. Thirdly, the construction of education digital intelligent campus of college students' ideology and politics should be constantly strengthened. The construction of digital intelligent campus provides a broad space and prospect for the development of higher education teaching, and at the same time provides an unprecedented good opportunity for the ideological and political education of college students. Therefore universities and colleges should give full play to the advantages of digital media information, focus on improving and developing college ideological and political theory courses online course teaching platform. Teachers of ideological and political theory course can upload their own teaching design, teaching plan and teaching courseware through the platform to realize the sharing of teaching resources. And they can finish the assignment and correction of work on the platform, and set up an online communication platform where they can achieve real-time communication with students and make effective corresponding to the issues popularly concerned. In this way students can have opportunities to fully express their own ideas and clear up the doubt; and teachers can understand students' ideas timely and implement targeted ideological and political education.

\section{Establishing a Scientific Evaluation Mechanism}

In the implementation of experiential ideological and political education in colleges and universities, attention should be paid not only to the process of experience, but also to the results of experience. Establishing scientific evaluation mechanism is the key factor to strengthen the education 
effect of experiential ideology and politics, and also an important guarantee to improve the effectiveness and impartiality of the evaluation system. In addition to the assessment specific theoretical aspects, but the practical aspects of the assessment should also be paid attention to. The process evaluation mechanism should be introduced to encourage college students' enthusiasm and initiative to participate in the ideological and political education practice so that they will value the experiential process and gain something mentally thus achieve the expected education effect. First of all, the evaluation subject should be multiple instead of single. The traditional education evaluation mode of ideological and political education which takes ideological and political educators as a single evaluation subject should be changed and diversified evaluation subjects including educators, students, parents and society should be included in the education evaluation mode. The core role of student evaluation should be respected so that the smooth development of experiential ideological and political education can be constantly promoted. Secondly, the evaluation system should be comprehensive instead of onesided. In addition to the traditional theoretical evaluation, the assessment of practical link should also be paid attention to, so that students can be inspired to take party in practical activities experiential ideological and political education. And in this process, not only the social practice activity report, but also the actual performance of students should be accessed, thus they can be comprehensively, objectively and scientifically evaluated. And finally can the evaluation mechanism be transformed from the result evaluation to the process evaluation. Since college students at different stages of development have obvious differences in thought, body and mind, their differences must be taken full account of. Evaluation criterion for different stages should be formulated and corresponding adjustments should be made as students' grades change. All in all, it is not enough to only pay attention to the resultant evaluation, but also to the evaluation in the process of education.

\section{CONCLUSION}

The implementation of experiential education is of great significance for improving the effect of education and improving the comprehensive quality and ability of college students. With the rich content involving a wide range of the ideological and political education, students can achieve selfexperience, self-cognition, and ultimately self-development and self-improvement through specific educational activities. In the process of experiential education, education workers should actively explore, give students full space to experience, and enhance their interest and enthusiasm in education activities. At the same time, educators should also carefully select and study practical programs, implement effective methods, and constantly improve the pertinence and effectiveness of education ideological and political education for college students. In this way can the "cultivating" role of education be achieved to promote the ideological and moral quality of college students?

\section{REFERENCES}

[1] The CPC Central Committee and the State Council. Opinions on further strengthening and improving the ideological and political education of college students. 2004. (in Chinese)

[2] Wang Tiansi. Celebrity experience [M]. Nanchang: Jiangxi People's Publishing House, 1996:1. (in Chinese)

[3] B.Joseph pine, James H. Gilmore. Experience Economy [M]. translated by Xia Yeliang, Lu Wei. Beijing: China Machine Press, 2002:18-19.

[4] Xue Baohong. Experience education innovation principle and method [M]. Beijing: China zhijian Publishing House, 2012:4-5. (in Chinese)

[5] Chen Jianxing. Psychological analysis and practical exploration of experiential education [J]. Journal of Technology College Education, 2006, (2). (in Chinese)

[6] Lin Jing. Research on the construction of education three-dimensional model of ideological politics and politics in universities. Beijing: People's Publishing House, 2017:47. (in Chinese) 